\title{
PERBEDAAN KADAR HEMOGLOBIN DAN STATUS GIZI PADA PERSALINAN NORMAL DAN PREMATUR
}

\section{DIFFERENCES OF HEMOGLOBIN LEVELS AND NUTRITIONAL STATUS IN NORMAL AND PRETERM LABOUR}

\author{
Supratiknyo, Siti Mardiyah \\ Akademi Kebidanan Ibrahimy Sukorejo Situbondo \\ Email:Supratiknyo@akbidibrahimy.ac.id
}

\begin{abstract}
ABSTRAK
Prematur merupakan penyebab utama 60-80\% morbiditas dan mortalitas neonatal di seluruh dunia. Hemoglobin $(\mathrm{Hb})$ dan status gizi yang rendah pada ibu hamil salah satu faktor yang dapat mempengaruhi persalinan prematur. Penelitian ini bertujuan untuk mengetahui perbedaan kadar hemoglobin dan status gizi di normal dan kelahiran prematur di rumah sakit Abdoer Rahem Situbondo. Desainnya adalah analitik komparatif dengan pendekatan cross sectional. Populasi penelitian adalah normal dan prematur ibu melahirkan adalah 68 ibu. Metode sampling yang digunakan adalah total sampling dengan sampel 68 responden, teknik pengumpulan data pengambilan dengan rekam medis dan dilaksanakan pada tahun 2015. Hasil penelitian menunjukkan tidak ada perbedaan dalam tingkat $\mathrm{Hb}$ dan status gizi di persalinan normal dan prematur. Hasil uji Chi-Square menunjukkan bahwa hasil dari Pvalue $=0,000>0,05$ maka H0 ditolak. Jadi dapat disimpulkan bahwa ada perbedaan antara kadar hemoglobin dan status gizi di persalinan normal dan prematur.
\end{abstract}

Kata kunci : Wanita Hamil, Kadar Hemoglobin, Status Gizi.

\begin{abstract}
Premature was the main cause of $60-80 \%$ neonatal morbidity and mortality worldwide. Hemoglobin $(\mathrm{Hb})$ and low nutritional status in pregnant women was one of the factors that can affect preterm labor. This study aims to determine differences in hemoglobin levels and nutritional status in normal and premature birth in Abdoer Rahem Situbondo hospital. The design used a comparative analitic with cross sectional approach. The study population was normal and premature delivery was 68 mothers. The sampling method used total sampling with 68 respondents samples, data collection technique with medical record and implemented in 2015. The results showed that there wa difference in $\mathrm{Hb}$ level and nutritional status in normal and premature labor. Chi-Square test results showed P-value $=0,000>0.05$ then $\mathrm{HO}$ was ignored. So it can be concluded that there was a difference between hemoglobin levels and nutritional status in normal and premature labor.
\end{abstract}

Keywords : Pregnant Women, Hemoglobin Levels, Nutritional Status.

\section{PENDAHULUAN}

Angka kematian bayi (AKB) di Propinsi Jawa Timur pada tahun 2007 sebesar 35 per 1.000 kelahiran hidup. Menurut data badan pusat statistik (BPS) menyebutkan bahwa AKB Provinsi Jawa Timur tahun 2009 sebesar 31,41 per 1.000 kelahiran hidup. Pada tahun 2010 angka kematian bayi terdapat 29,99 per 1.000 kelahiran hidup tahun 2011 angka kematian bayi sebanyak 29,24 per 1.000 kelahiran hidup dan angka kematian bayi 30 per 1.000 kelahiran hidup di tahun 2012 sedangkan angka kematian balita sebanyak 34 per 1.000 kelahiran hidup.

Persentase kelahiran prematur 
dan BBLR sangat tinggi. Angka bertahan hidup bayi meningkat sesuai dengan tingkat disabilitas relatif terhadap usia gestasi (Chapman, 2006). Semakin muda usia kehamilan, semakin tinggi angka kematian perinatal. Umur kehamilan yang kurang, menyebabkan bayi yang lahir belum sepenuhnya dapat beradaptasi dengan lingkungan di luar kandungan, sehingga angka morbiditas dan mortalitas perinatal meningkat. Dampak negatif tidak saja terhadap morbiditas dan mortalitas perinatal, tetapi juga terhadap potensigenerasi yang akan datang, kelainan mental dan beban ekonomi bagi keluarga dan bangsa secara keseluruhan (Wiknjosastro,2005).

Prematur merupakan penyebab utama $60-80 \%$ morbiditas dan mortalitas neonatal di seluruh dunia. Data Dinas Kesehatan Provinsi Jawa Timur menunjukkan angka kejadian partus prematurus tahun 2010 sebesar 1,29\% dari total kelahiran hidup. Angka tersebut mengalami peningkatan bila dibandingkan dengan tahun 2009 yang sebesar $1,11 \%$. Kota Surabaya sendiri pada tahun 2010 menduduki peringkat kedua setelah Kota Malang dengan jumlah kejadian persalinan prematur sebanyak 559 kasus. Data dari Rumkital Dr. Ramelan Surabaya menunjukkan jumlah persalinan prematur pada tahun 2012 sebesar 7,77\% dari total jumlah persalinan.

Data yang di dapat dari dinas kesehatan jumlah persalinan prematur sebanyak 163 tahun 2013, pada tahun 2014 persalinan premature sebanyak 212. Berdasarkan studi pendahuluan pada tanggal 11-mei-2015 yang dilakukan peneliti di RSUDdr. AbdoerRahem tercatat jumlah persalinan premature sebanyak $37(52,1 \%)$ dan persalinan normal sebanyak $34(47,8 \%)$ pada tahun 2015 .

Menurut Manuaba (2001) terjadinya penyebab persalina prematur di sebabkan oleh faktor individu; keadaan sosial ekonomi (pekerjaan, gizi), penyakit sistemik bumil (paru, jantung, lever, DM, hipertensi, infeksi organ vital), infeksi kehamilan (korioamnionitis, servisitis-endometritis, infeksi plasenta).

Penyebab persalinan prematur bersifat multifaktorial dan melibatkan interaksi kompleks antara faktor fetus, plasenta, uterus dan maternal. Dari faktor penyebab persalinan prematur yang berhubungan dengan kadar hemoglobin dari segi plasenta adalah adanya infeksi dan infusiensi plasenta. Dari maternal sendiri penyebab 
persalinan prematur yang berkenaan dengan hemoglobin (Nugroho, 2005).

Selain adanya infusiensi plasenta dan hipertensi faktor penyebab dari partus prematur adalah gizi. Gizi yang baik mempunyai adil yang cukup besar pada pembentukan kualitas sel darah merah dimana kekurangan gizi berdampak negatif pada kesehatan dan dapat menghambat kualitas sel darah merah seperti yang diharapkan. Bila kekurangan gizi terjadi pada ibu hamil maka akan berakibat buruk baik bagi ibu itu sendiri maupun anak yang dilahirkannya. Dalam hal ini dengan status gizi yang tidak baik akan mengakibatkan berat badan bayi tidak normal dan terjadi partus prematur.

Sampai saat ini, masih banyak ibu hamil mengalami masalah gizi khususnya gizi kurang, seperti masalah kurang energi kronis dan anemia gizi (prasetyono, 2008 ). Frekuensi ibu hamil Di indonesia relative tinggi yaitu $63,5 \%$,sedangkan di Amerika hanya $6 \%$,kekurangan gizi dan perhatian yang kurang terhadap ibu hamil merupakan predisposisi anemia defisiensi ibu hamil di Indonesia ( Prawirohardjo,2007 ).

Hemoglobin dan status gizi sangat berkaitan erat dalam kesejahteraan kesehatan ibu hamil untuk melahirkan dengan lancar dan menghasilkan keturunan yang unggul baik dari segi pertumbuhan maupun perkembangan janin. Oleh karena itu seorang ibu hamil perlu memperhatikan asupan makanan bergizi dan seimbang. Hal ini karena calon ibu tidak lagi sendiri melainkan berdua yakni dengan calon anak yang dikandungnya. Dengan asupan gizi yang baik selama hamil, maka akan menyebabkan suplai kebutuhan gizi untuk pertumbuhan janin terpenuhi dengan baik. Jika tidak maka pertumbuhan untuk tubuh ibu tidak terpenuhi dan akan melahirkan bayi kecil atau prematur (prasetyono, 2008).

Berdasarkan latar belakang yang diatas maka penulis tertarik untuk melakukan penelitian tentang "Perbedaan kadar HB dan status gizi pada persalinan normal dan persalinan prematur di RSUD dr. Abdoer Rahem Situbondo.

\section{METODE PENELITIAN}

Jenis penelitian analitik komparatif dengan menggunakan pendekatan cross sectional yang berusaha melihat kebelakang, artinya pengumpulan data dimulai dari efek atau akibat yang terjadi. Kemudian dari efek tersebut di telusuri kebelakang tentang 
penyebab atau variabel-variabel yang mempengaruhi akibat tersebut (Notoaimodjo, 2012). Tehnik sampling penelitian adalah total sampling sebanyak 68 ibu persalinan normal dan persalinan prematur. Berdasarkan kriteria inklusi Penelitian ini akan dilaksanakan di RSUD Abdoer Rahem Situbondo. Varibel independen dalam penelitian ini adalah persalinan normal dan pesalinan prematur. sedangkan variabel dependen adalah kadar $\mathrm{Hb}$ dan status gizi. Instrumen penelitian ini menggunakan rekam medik dengan mencatat data persalinan normal dan persalinan prematur. Selanjutnya data diuji dengan menggunakan Chi-square.

\section{HASIL DAN PEMBAHASAN}

Berdasarkan hasil uji statistik didapatkan hasil sebagaimana didalam tabel:

Tabel 1 Distribusi Frekuensi Responden berdasarkan pendidikan di RSUD Abdoer Rahem Situbondo

\begin{tabular}{|c|c|c|c|}
\hline No & Pendidikan & Frekuensi & Presentase \\
\hline 1 & SD & 20 & $29 \%$ \\
\hline 2 & SMP & 15 & $22 \%$ \\
\hline 3 & SMA & 20 & $29 \%$ \\
\hline 4 & PT & 13 & $20 \%$ \\
\hline & Total & 68 & $100 \%$ \\
\hline
\end{tabular}

data hampir setengahnya responden berpendidikan SMA (sekolah menengah keatas) berjumlah 20 orang (29\%) sedangkan sebagian kecil responden berpendidikan PT (perguruan tinggi) berjumlah 13 orang (20\%).

Tabel 2 Distribusi Frekuensi Responden berdasarkan umur di RSUD Abdoer Rahem Situbondo

\begin{tabular}{|c|c|c|c|}
\hline No & Umur & Frekuensi & Persentase \\
\hline 1 & $>20$ & 28 & $41,1 \%$ \\
\hline \multirow[t]{2}{*}{2} & $>30$ & 40 & $58,8 \%$ \\
\hline & Total & 68 & $100 \%$ \\
\hline
\end{tabular}

data hampir setengahnya responden pada kelompok umur $>30$ tahun berjumlah 40 orang $(58,8 \%)$.

Tabel 3 Distribusi Frekuensi Responden berdasarkan $\mathrm{Hb}$ di RSUD Abdoer Rahem Situbondo

\begin{tabular}{|c|c|c|c|}
\hline $\begin{array}{l}\mathbf{N} \\
\mathbf{0}\end{array}$ & $\begin{array}{c}\text { Hemoglobin } \\
\text { (Hb) }\end{array}$ & Frekuensi & Persentase \\
\hline 1 & Normal & 40 & $58,8 \%$ \\
\hline \multirow[t]{2}{*}{2} & Tidak normal & 28 & \\
\hline & Total & 68 & $\begin{array}{l}41.1 \% \\
100 \%\end{array}$ \\
\hline & Berdasarkan & tabel & dapat \\
\hline
\end{tabular}

dilahat dari hasil persalinan normal hampir semua resonden ibu memiliki $\mathrm{Hb}$ normal yaitu berjumlah 36 orang $(52,9 \%)$.

Tabel 4 Distribusi Frekuensi Responden berdasarkan status gizi di RSUD Aboer Rahem Situbondo

\begin{tabular}{cccc}
\hline No & Status gizi & Frekuensi & Persentase \\
\hline 1 & Kurus & 32 & $47,0 \%$ \\
2 & Normal & 0 & $0 \%$ \\
3 & Gemuk & 23 & $33,8 \%$ \\
4 & Sangat & 13 & $19,1 \%$ \\
& gemuk & & \\
& Total & 68 & $100 \%$ \\
\hline
\end{tabular}

Berdasarkan tabel 4 dapat dilahat dari hasil hampir seluruhnya responden kurus yaitu berjumlah 32 orang $(47,0 \%)$ dan responden yang status gizinya normal yaitu $0(0 \%)$. 
Tabel 5 Distribusi Frekuensi Responden berdasarkan persalinan normal dan prematur di RSUD Abdoer Rahem Situbondo

\begin{tabular}{ccccc}
\hline No & Persalinan & UK & Frekuensi & $\begin{array}{c}\text { Persen } \\
\text { tase }\end{array}$ \\
\hline 1 & Normal & $>37$ & 34 & $50 \%$ \\
2 & Prematur & $<37$ & 34 & $50 \%$ \\
& Total & & 68 & $100 \%$ \\
\hline
\end{tabular}

Berdasarkan tabel 5. dapat dilihat dari hasil persalinan normal hampir memiliki jumlah 34 orang $(50 \%)$ dan persalinan prematur yaitu 34 orang $(50 \%)$.

Tabel 6 Distribusi Frekuensi Responden berdasarkan $\mathrm{Hb}$ di RSUD Abdoer Rahem Situbondo

\begin{tabular}{|c|c|c|c|c|c|c|c|c|}
\hline \multirow{2}{*}{$\begin{array}{l}\mathbf{N} \\
\mathbf{0}\end{array}$} & \multirow[t]{2}{*}{ Hb } & \multicolumn{2}{|c|}{$\begin{array}{l}\text { Persali } \\
\text { nan } \\
\text { normal }\end{array}$} & \multicolumn{2}{|c|}{$\begin{array}{c}\text { Persali } \\
\text { nan } \\
\text { premat } \\
\text { ur }\end{array}$} & \multicolumn{2}{|c|}{ Total } & \multirow[t]{2}{*}{$\begin{array}{c}\text { P- } \\
\text { value }\end{array}$} \\
\hline & & $\mathbf{F}$ & $\%$ & $\mathbf{F}$ & $\%$ & $\mathbf{F}$ & $\%$ & \\
\hline 1 & $\begin{array}{l}\mathrm{Hb} \\
\text { nor } \\
\text { mal }\end{array}$ & 15 & 22 & 25 & 37 & 40 & 59 & \\
\hline 2 & $\begin{array}{l}\mathrm{Hb} \\
\text { tida } \\
\mathrm{k} \\
\text { nor } \\
\text { mal }\end{array}$ & 19 & 28 & 9 & 13 & 28 & 41 & 0,00 \\
\hline & Total & 34 & 50 & 34 & 50 & 68 & $\begin{array}{c}10 \\
0\end{array}$ & \\
\hline
\end{tabular}

Berdasarkan tabel 6 dapat dilihat dari responden kadar $\mathrm{Hb}$ normal yang mengalami persalinan normal yaitu 15 orang $(22,0 \%)$, dan $\mathrm{Hb}$ tidak normal pada persalinan normal yaitu 19 orang (27,9\%), sedangkan kadar $\mathrm{Hb}$ normal yang mengalami persalinan prematur yaitu 25 orang $(36,7 \%)$ dan pada kadar $\mathrm{Hb}$ tidak normal yaitu 9 orang $(13,2 \%)$.
Sementara dari hasil penghitungan data peneliti dengan menggunakan uji Chi-Square dengan SPSS menunjukkan bahwa hasil dari Pvalue pada kolom sign (2-tailed) $=0,000$ $<0,05$ maka $\mathrm{H}_{1}$ diterima dan $\mathrm{H}_{0}$ ditolak. Sehingga dapat ditarik kesimpulan bahwa ada perbedaan antara kadar hemoglobin pada persalinan normal dan prematur.

Tabel 7 Distribusi Frekuensi Responden berdasarkan status gizi di RSUD Abdoer Rahem Situbondo

\begin{tabular}{ccccccccc}
\hline $\begin{array}{l}\text { N } \\
\text { o }\end{array}$ & $\begin{array}{l}\text { Stat } \\
\text { us } \\
\text { gizi }\end{array}$ & $\begin{array}{c}\text { Persalinan } \\
\text { normal }\end{array}$ & $\begin{array}{c}\text { Persalinan } \\
\text { prematur }\end{array}$ & Total & $\begin{array}{c}\text { P- } \\
\text { value }\end{array}$ \\
\hline 1 & $\begin{array}{c}\text { Kur } \\
\text { us }\end{array}$ & 10 & 15 & 22 & 32 & 32 & 47 & \\
2 & $\begin{array}{l}\text { Nor } \\
\text { mal }\end{array}$ & 0 & 0 & 0 & 0 & 0 & 0 & \\
& $\begin{array}{l}\text { Ge } \\
\text { mu } \\
\text { k }\end{array}$ & 15 & 22 & 8 & 11 & 23 & 34 & 0,00 \\
& $\begin{array}{l}\text { San } \\
\text { gat } \\
\text { gem }\end{array}$ & 9 & 13 & 4 & 6 & 13 & 19 & \\
uk & & & & & & & & \\
Total & 34 & 50 & 34 & 50 & 68 & 100 & \\
\hline
\end{tabular}

Berdasarkan tabel 7 dapat dilihat dari responden status gizi kurus yang mengalami persalinan normal yaitu 10 $(14,7 \%)$, pada status gizi normal yaitu 0 orang $(0 \%)$, sedangkan status gizi gemuk yaitu 15 orang $(22,0 \%)$, dan pada status gizi sangat gemuk yaitu 9 orang $(13,2 \%)$, sedangkan pada status gizi kurus yang mengalami persalinan prematur yang mengalami status gizi 
kurus yaitu 22 orang $(23,3 \%)$ pada status gizi normal yaitu 0 orang $(0 \%)$ sedangkan pada status gizi gemuk yaitu 8 orang $(11,7 \%)$ dan pada status gizi yang sangat gemuk yaitu 4 orang $(8,5 \%)$.

Sementara dari hasil penghitungan data peneliti dengan menggunakan uji Chi-Square dengan SPSS menunjukkan bahwa hasil dari Pvalue pada kolom sign $(2$-tailed $)=0,000$ $<0,05$ maka $\mathrm{H}_{1}$ diterima dan $\mathrm{H}_{0}$ ditolak. Sehingga dapat ditarik kesimpulan bahwa ada perbedaan antara status gizi pada persalinan normal dan prematur.

Pada persalinan prematur tidak cuma bisa di di pengaruhi oleh rendahnya kadar hemoglobin tapi juga bisa di pengaruhi oleh faktor lain seperti mempuyai riwayat persalina gameli, ketuban pecah dini, riwayat peyakit penyerta sehingga ibu tersebut dapat mengalami persalinan prematur. Masih banyak kejadian persalinan prematur dengan status gizi kurang dan pada penelitian tersebut juga ditemukan bahwasanya persalinan prematur salah satunya di pengaruhi dari status gizi kurang, melainkan persalinan premature juga bisa di sebabkan oleh factor lain seperti umur ibu, tingkat pendidikan, riwayat penyakit.
Kadar $\mathrm{Hb}$ yang rendah mengakibatka resiko persalinan prematur. Kadar hemoglobin untuk stauts anemia gizi besi,menyataka hemoglobin $(\mathrm{Hb})$ adalah bentuk konjngsi $\mathrm{Fe}$ dengan protein dalam bentuk aktif dalam bentuk ferro yang berfungsi mentanspor $\mathrm{CO} 2$ dari jaringan paru-paru ntuk diekresikan kedalam udara pernapasan dengan membawa $\mathrm{O} 2$ dari paru-paru ke sel -sel jaringan. Hemoglobin terdapat didalam sel darah merah. Pada penelitian ini 28 responden yang mengalami persalinan premature. Hal ini di karenakan kurangnya kadar hemoglobin, sehingga pengenceran dalam darah yang terjadi dalam kehamilan menyebabkan konsentasi hemoglobin dalam darah menjadi rendah.

Sedangkan pada status gizi ibu yang mengalami persalinan normal berat badan dikategorikan normal dan cenderung pada berat badan rendah akan terjadi persalinan prematur, masalah kekurangan dan kelebihan gizi merupakan masalah penting terutama bagi ibu hamil yang mau menghadapi proses pesalinan, karena selain ada resiko tertentu, juga akan mempengaruhi pertumbuhan janin dalam kandungan, oleh karena itu pemantaun keadaan 
tersebut perlu dilakukan secara berkesinambungan. Salah satunya mempertahankan berat badan yang ideal atau normal (Waryana, 2010) dan pada status gizi pada ibu yang proses persalinan sangat dibutuhkan. Sehingga asupan gizi yang baik selama hamil akan menyebabkan pertumbuhan janin terpenuhi dan pada status gizi yang berdsarkan hasil IMT juga berhubungan dengan kejadian persalinan prematur.

\section{SIMPULAN DAN SARAN}

Bedasarkan hasil penelitian dan pembahasan dapat disimpulkan yaitu, Sebagian besar responden memiliki kadar hemoglobin normal namun mengalami persalinan prematur, yaitu 25 orang (36,7\%), Sebagian besar responden mengalami status gizi kurus dan mengalami persalinan premature, yaitu 22 orang $(23,3 \%)$, Ada perbedaan kadar hemoglobin dan status gizi pada persalinan normal dan prematur. Penelitian selanjutnya diharapkan dapat melanjutkan peneliti ini untuk meningkatkan pelayanan kesehatan khususnya tentang penberian vitamin $\mathrm{Fe}$ dan nutrisi yang dibutuhkan oleh ibu yang akan menghadapi prose persalinan, petugas yang terkait dapat memberikan KIE tentang butuhnya vitamin $\mathrm{Fe}$ dan nutrisi ibu bersalin lebih adekuat untuk meningkatkan derajat kesehatan ibu dan janin. Hasil penelitian ini diharapkan dapat menjadi sumbangsi dalam bidang penelitian kesehatan terutama pada ibu yang akan menghadapi persalinan dan sebagai tambahan perluasan ilmu yang dapat di lahan atau di institusi.

\section{DAFTAR PUSTAKA}

Budiarto, 2012. Biostatika untuk Kedokteran dan Kesehatan Masyarakat Jakarta ECG.

Chapman,V, 2006. Asuhan Kebidanan Persalinan dan Kelahiran Jakarta : ECG. P:184 203

Huliana, 2008, Perawatan Kehamilan. Jogjakayta. Diva press.

Manuaba, IBG. 2001. Penuntun Kepaniteriaan Klinik Obstetri dan Ginikologi. Jakarta:ECG.P:75-7

Notoatmodjo, 2012. Metodelogi Penelitian Kesehatan. Jakarta Rineka Cipta.

Nugroho taufan,2012. Patologi Kebidanan Yogyakarta : Numed

Prasetyono, 2008. Bimbingan dan Persiapan dan Perawatan Kehamilan. Jogjakayta. Diva press.

Prawihardjo, 2008. Ilmu Kebidanan Jakarta BP-SP.

Prawihardjo, sarwono. 2011. Ilmu Kebidanan Jakarta BP-SP.

Rachmawati, 2007. Asuhan Kebidanan Persalinan dan Kelahiran Jakarta

Riskiyah dkk, 2014, Metode Ilmu Gizi Jakarta. 
Rukiyyah, 2010. Asuhan Kebidanan Persalinan dan Kelahiran Jakarta :ECG

Sumarah, Nining Wiyati, Yani Widiastutik, 2008. Perawatan Ibu Bersalin (Asuhan Kebidanan Pada Ibu Bersalin. Yogyakart
Sulistiyawati, ari, 2010. Asuhan Kebidanan Ibu Bersalin. Jakarta Selemba Medika

Solihah, 2010. Asuhan Kebidanan Ibu Bersalin. Jakarta 